\title{
Serological survey of Rickettsia in equids from Vale do Paraíba, São Paulo, Brazil, and their tick identification and molecular investigation of Rickettsia
}

\author{
Levantamento sorológico de Rickettsias em equinos no Vale do Paraíba, \\ São Paulo, Brasil. Identificação e pesquisa molecular de Rickettsias em \\ carrapatos
}

\begin{abstract}
Claudia Iorio Budweg ${ }^{1}$; Amanda Oliveira de Sousa ${ }^{2}$ (D); Tânia Regina Vieira de Carvalho ${ }^{1}$ (D); Zahi Êni Santos Souza ${ }^{1}$; Maria Carolina de Azevedo Serpa ${ }^{2}$; Thiago Fernandes Martins²; Fernanda Nieri-Bastos²; Arlei Marcili ${ }^{1,2}$ (1); Marcelo Bahia Labruna ${ }^{2}$ (D); Jonas Moraes-Filho ${ }^{1,2}$ (i)

\author{
${ }^{1}$ Universidade Santo Amaro, Mestrado em Medicina e Bem-Estar Animal, São Paulo - SP, Brazil \\ ${ }^{2}$ Universidade de São Paulo, Faculdade de Medicina Veterinária e Zootecnia, Departamento de Medicina Veterinária Preventiva e Saúde \\ Animal, São Paulo - SP, Brazil
}

\begin{abstract}
Brazilian spotted fever is a serious and lethal illness for humans and is caused by the Rickettsia rickettsii bacteria. In the state of São Paulo/SP (Brazil), the etiological agent of this disease is transmitted by the Amblyomma sculptum tick. It was already shown that horses infected with this bacteria produce a strong immune response and could be important sentinels for the detection of the disease in a proper region. The present investigation performed a serological survey in horses from five farms of Vale do Paraíba, São Paulo state, Brazil, searching for antibodies against, Rickettsia rickettsii, Rickettsia parkeri, Rickettsia amblyommatis, Rickettsia rhipicephali, and Rickettsia bellii. In each farm, ticks were also collected that were taxonomically identified and examined by real-time PCR for Rickettsia spp DNA. Blood samples were collected from 206 horses, and 334 ticks were picked up from these animals from January to December 2017. Eighty ticks were A. sculptum and 254 Dermacentor nitens. Of the blood samples, $7.3 \%$ seroconverted to Rickettsia spp. Of these, $0.97 \%$ had a positive serological response to $R$. bellii. None of the $80 \mathrm{~A}$. sculptum ticks were positive through real-time PCR for Rickettsia spp. Although there was no detection of ticks infected by Rickettsia spp in five farms of Paraíba Valley, the horses presented serological positive reactions against this agent. Thus, further large studies should be conducted in the area targeting hosts and vectors to generate data for control measures of the transmission of Brazilian spotted fever.
\end{abstract}

Keywords: Ticks. Amblyomma. Dermacentor. qPCR. Host.

\section{RESUMO}

A febre maculosa brasileira é uma doença grave e letal para seres humanos causada pela bactéria Rickettsia rickettsii. No estado de São Paulo, SP, Brasil, o agente etiológico desta enfermidade é transmitido pelo carrapato Amblyomma sculptum. Conforme descrito na literatura científica, os cavalos infectados com esta bactéria produzem uma forte resposta imune e podem ser importantes sentinelas para a deteç̧ão da doença. A presente investigação realizou um levantamento sorológico em cavalos de cinco fazendas do Vale do Paraíba, São Paulo, Brasil, à procura de anticorpos contra Rickettsia rickettsii, Rickettsia parkeri, Rickettsia amblyommatis, Rickettsia rhipicephali e Rickettsia bellii. Em cada fazenda, também foram coletados carrapatos identificados taxonomicamente e examinados por PCR em tempo real para o DNA de Rickettsia spp. Foram coletadas amostras de sangue de 206 cavalos e coletados 334 carrapatos desses animais entre os meses de janeiro e dezembro de 2017. Oitenta carrapatos foram identificados como A. sculptum e 254 Dermacentor nitens. Das amostras de sangue, 7,3\% soroconverteram para Rickettsia spp., sendo que, 0,97\% apresentaram soropositividade homóloga para R. bellii. Nenhum dos 80 carrapatos de A. sculptum foi positivo com o emprego de PCR em tempo real para Rickettsia spp. Embora não tenham sido detectados carrapatos infectados por Rickettsia spp em cinco fazendas do Vale do Paraíba, os animais apresentaram reações sorológicas positivas para este agente. Assim, outros estudos abrangentes deverão ser realizados na área investigando hospedeiros e vetores, gerando dados para medidas de controle da transmissão da febre maculosa brasileira.

Palavras-chave: Carrapatos. Amblyomma. Dermacentor. qPCR. Hospedeiro. 
Correspondence to:

Jonas Moraes-Filho

Universidade Santo Amaro

Rua Isabel Schmidt, 349, Santo Amaro

CEP: 04743-030, São Paulo - SP, Brazil

e-mail: jonasmfilho@hotmail.com

Received: May 21, 2019

Approved: September 20, 2019

How to cite: Budweg CI, Sousa AO, Carvalho TRV, Souza ZES, Serpa MCA, Martins TF, Nieri-Bastos F, Marcili A, Labruna MB, Moraes-Filho J. Serological survey of Rickettsia in equids from Vale do Paraiba, São Paulo, Brazil, and their tick identification and molecular investigation of Rickettsia. Braz J Vet Res Anim Sci. 2019;56(4):e158159. https://doi.org/10.11606/issn.1678-4456.bjvras.2019.158159

\section{Introduction}

Brazilian spotted fever (BSF) is a tick-borne zoonosis caused by the bacterium Rickettsia rickettsii, first described in the United States, where the disease was called Rocky Mountain spotted fever (Ricketts, 1909). In Brazil, the disease was first described in 1929 in São Paulo (Piza, 1932) and its transmission was confirmed by tick species of Amblyomma sculptum (former Amblyomma cajennense) (Lemos-Monteiro et al., 1932).

The primary hosts for A. sculptum in endemic areas for BSF are capybaras (Hydrochoerus hydrochaeris) and horses (Equus caballus) (Aragão, 1936; Vieira et al., 2004). Equines are animals that can play a fundamental role in the epidemiological chain of BSF because they have free movement and can disseminate infected ticks, spreading the disease to different regions (Cardoso et al., 2006; Medeiros et al., 2013). Ueno et al. (2016) evaluated horses after either intravenous inoculation of $R$. rickettsii or infestation by $R$. rickettsii-infected ticks, demonstrating that, in both cases, this bacteria was able to infect horses, inducing immune response, but without bacteremia and clinical manifestations of the disease. These experimentally infected horses were not a source of infection for the uninfected ticks that had fed on them during $R$. rickettsii infection. Therefore, Ueno et al. (2016) demonstrated that although horses were not amplifying hosts of $R$. rickettsii for ticks, these animals are efficient sentinels for the epidemiological surveillance of rickettsial diseases, since they develop an effective and lasting humoral immune response after $R$. rickettsii infection.

The Paraíba Valley, in the state of São Paulo, Brazil, is an area where rural tourism is of significant economic importance, with several horse stables and riding centers.
It is an area characterized by abundant vegetation and the presence of wild animals, such as capybaras, which may favor the maintenance of tick species vectors of Brazilian spotted fever and, consequently, Rickettsia spp. The region has presented human cases of Brazilian spotted fever in the last 10 years, with emphasis on the cities of São José dos Campos and Jacarei, with disease lethality rates of $50 \%$ and 100\%, respectively (Centro de Vigilância Epidemiológica Prof. "Alexandre Vranjac, 2019).

Thus, this work performed a serological survey of Rickettsia spp antibodies in horses of farms located in the Paraíba Valley, São Paulo state, Brazil, collected ticks from these horses, and investigated the presence of Richettsia spp DNA on them by real time PCR.

\section{Material and Methods}

The population of this study was horses from five intensive farms located in the Vale do Paraíba of the state of São Paulo. The farms were named as A ( $\left.23^{\circ} 17^{\prime} 46.87^{\prime \prime} \mathrm{S} ; 46^{\circ} 01^{\prime} 05.98^{\prime \prime} \mathrm{O}\right)$,

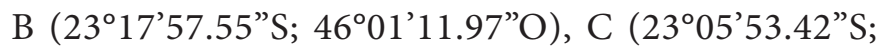

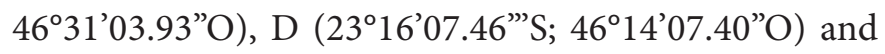
E ( $23^{\circ} 15^{\prime} 53.46^{\prime \prime}$; $\left.45^{\circ} 57^{\prime} 30.03^{\prime \prime} \mathrm{O}\right)$, according to Figure 1.

The region has a subtropical climate, with rainy and warm summers, and dry and cool winters. The local vegetation is a remaining of Atlantic Rainforest, with annual temperatures ranging from 18 to $19^{\circ} \mathrm{C}$ (Martinelli, 2010).

All field activities were performed with consent of animal owners and all procedures were authorized by Ethics Committee of Universidad Santo Amaro, protocol number 31/2016. Blood samples and ticks were collected from January to December 2017.

Blood samples were aseptically obtained by jugular venipuncture with $30 \times 7 \mathrm{~mm}$ needle and $5 \mathrm{ml}$ syringe, being kept at room temperature and then centrifuged to obtain the serum, which was aliquoted and stored at $-20^{\circ} \mathrm{C}$ until the time of processing. From the 206 equines examined, 136 were from farm A, five from farm B, 11 farm C, 43 farm D, and 11 farm E.

Equine sera were tested by immunofluorescence assay (Horta et al., 2004). The used antigens were $R$. rickettsii (Taiaçu strain), R. parkeri (At24 strain), R. bellii (Mogi strain), R. amblyommatis (published as Rickettsia amblyommii) (Ac37 strain) and R. rhipicephali (HJ\#5 strain), maintained at the FMVZ-USP Parasitic Disease Laboratory, in cell culture (vero cells) (Labruna et al., 2004, 2007; Pinter \& Labruna, 2006; Silveira et al., 2007). Samples that had a positive reaction at the screening dilution (1/64) were retested for determination of the endpoint titer (Horta et al., 2004). 


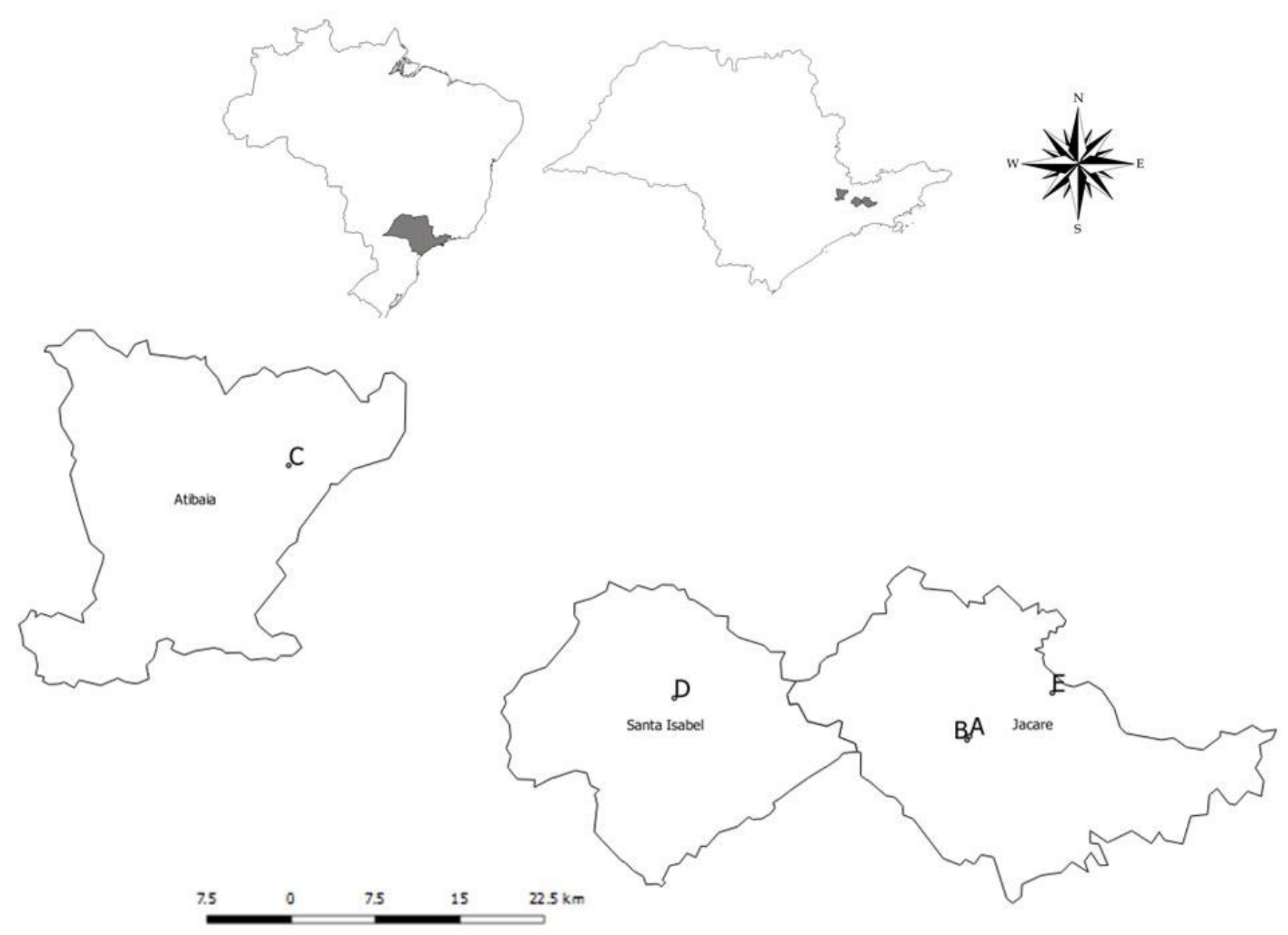

Figure 1 - Map with the locations of collection points.

The collected ticks were kept in bottles with $70^{\circ}$ alcohol, identified according to Barros-Battesti et al. (2006) and processed individually in the laboratory for DNA extraction, according to Sangioni et al. (2005). For detection of Rickettsia spp. through real-time TaqMan PCR, each extracted DNA sample was tested according to Guedes et al. (2005) and Labruna et al. (2004).

\section{Results}

The immunofluorescence assay detected antibodies in 15 (7.3\%) samples for at least one of the antigens analyzed: a) nine (4.4\%) against $R$. rickettsii, with titers ranging from 64 to 2,048 ; b) six (2.9\%) against $R$. parkeri, titers ranging from 64 to 1,$024 ; \mathrm{c}$ ) eight $(3.9 \%)$ against $R$. belli, titers ranging from 64 to 1,024; d) 11 (5.4\%) against $R$. amblyommatis, titers ranging from 64 to 1,024 ; e) eight (3.9\%) against R. rhipicephali, titers ranging from 64 to 1,024 .

Some samples obtained from all collection sites presented titers for a given antigen at least four times higher when compared to the values found for the other four etiologic agents analyzed, which is defined as most probable homologous antigen (PHA) (Ueno et al., 2016). For the other animals, it was not possible to determine which was the most probable infecting agent, since they presented similar values for the five antigens analyzed. Of the seroconverted samples for at least one species of Rickettsia, 13.4\% (2/15) had probable R. bellii homologous antigen (Table 1 ).

Ticks ( $\mathrm{n}=334)$ were collected only from horses of farms A ( $\mathrm{n}=253)$ and $\mathrm{D}(\mathrm{n}=81)$.

All of the ticks collected in farm A were taxonomically identified as Dermacentor nitens, with eight nymphs, two larvae, 158 females and 85 males.

The ticks collected in farm D were identified as 80 Amblyomma sculptum: 17 males, 57 females and six nymphs, and one $D$. nitens identified as a female.

All total of 80 tick specimens of the species A. sculptum were tested by real-time PCR for Rickettsia spp and none of them contained rickettsial DNA. 
Table 1 - Titers of positive samples of horses from Vale do Paraíba, SP, obtained by immunofluorescence assay against five different Rickettsia spp antigens. Blood collections performed from January to December 2017

\begin{tabular}{|c|c|c|c|c|c|c|c|}
\hline Sample & Farm & R. rickettsii & R. parkeri & R. bellii & R. amblyommatis & R. rhipicephali & PHA* \\
\hline 3 & A & 2048 & 1024 & 64 & 1024 & 1024 & Rickettsia spp \\
\hline 5 & $A$ & 128 & Negative & Negative & 128 & 128 & Rickettsia spp \\
\hline 20 & $A$ & 512 & 64 & Negative & 512 & 256 & Rickettsia spp \\
\hline 34 & $A$ & Negative & Negative & 512 & 256 & 128 & Rickettsia spp \\
\hline 65 & $A$ & 128 & Negative & Negative & 64 & Negative & Rickettsia spp \\
\hline 78 & $A$ & Negative & Negative & Negative & 64 & Negative & Rickettsia spp \\
\hline 81 & $A$ & Negative & Negative & 1024 & Negative & Negative & R. bellii \\
\hline 83 & $A$ & 512 & 64 & 512 & 128 & 64 & Rickettsia spp \\
\hline 87 & $A$ & Negative & Negative & 64 & Negative & Negative & Rickettsia spp \\
\hline 97 & $A$ & Negative & Negative & Negative & 64 & Negative & Rickettsia spp \\
\hline 98 & $A$ & 128 & 256 & 1024 & 256 & 1024 & Rickettsia spp \\
\hline 116 & $A$ & 128 & 64 & 256 & 256 & 128 & Rickettsia spp \\
\hline 119 & $A$ & Negative & Negative & 128 & Negative & Negative & R. bellii \\
\hline 120 & $A$ & 64 & 256 & Negative & 64 & 512 & Rickettsia spp \\
\hline 148 & $\mathrm{C}$ & 64 & Negative & Negative & Negative & Negative & Rickettsia spp \\
\hline
\end{tabular}

*PHA: probable homologous antigen.

\section{Discussion}

The Paraíba Valley, in the state of São Paulo, Brazil is an area where rural tourism is of significant economic importance, with several horse stables and riding centers. It is an area characterized by abundant vegetation and the presence of wild animals, such as capybaras, which may favor the maintenance of tick species vectors of Brazilian spotted fever and, consequently, Rickettsia spp. The region presented human cases of BSF in recent years, with lethality in some municipalities of 100\% (Centro de Vigilância Epidemiológica Prof. “Alexandre Vranjac, 2019).

Equines are primary hosts of $A$. sculptum in the state of São Paulo, and can seroconvert after infestation by ticks containing Rickettsia bacteria, demonstrating that, although they do not present clinical alterations, they are able to develop a humoral immune response, which enables them to be used as an excellent sentinel for BSF surveillance (Labruna et al., 2002; Ueno et al., 2016).

Although property A presented horses with serological positive responses to Rickettsia spp., no positive ticks were found on this farm. In farm D, where A. sculptum ticks were found, none of the 43 horses tested presented any positive result to Rickettsia spp., and the ticks were negative by PCR for rickettsia detection. After the results presented in these two studied areas, further studies must be performed to obtain a better knowledge about the probable vector responsible for the transmission of Rickettsia bacteria to these animals.

In farm $\mathrm{C}$, no ticks were found, but one animal reacted serologically to Rickettsia spp., indicating the possibility of the animal becoming infected in an area outside the farm boundaries. Both farms B and E did not have animals with positive responses to Rickettsia and no ticks were found during the blood collection. This is probably related to the fact that these farms were smaller, with easier animal handling and more intensive tick control.

The animals that responded serologically to Rickettsia probably did not become infected on their properties because the vectors of the disease were not found in these places, raising the suspicion that the infection could happen during exhibitions that the creators participated in or in walks in the region, mainly in trails and forest areas, which would facilitate tick contact with these animals.

In this work, a sample of 206 horses were tested for seroreactivity for five species of Rickettsia, indicating two seropositive horses homologous to the $R$. bellii antigen and most of the seroreactivity to the species of the spotted fever group were probably cross reactions, indicating that the animals probably were not exposed to agents of the macular fever group. $R$. bellii has been reported as the species of Rickettsia most commonly infecting ticks in Brazil (Krawczak et al., 2018; Labruna et al., 2011). This bacteria belongs to a rickettsial basal group that includes a variety of closely related agents infecting leeches, insects, protozoa, or even plants (Murray et al., 2016; Weinert et al., 2009), making it possible that these other organisms could be related to the seropositivity of $R$. bellii in the present study, a condition still not investigated.

Medeiros et al. (2013) demonstrated the occurrence of cross-reaction between different species of Rickettsia in horses. Positive serological responses in horses in areas with no tick exposure or negative serology in equines with tick exposure were described in different areas in Brazil (Batista et al., 2010; Pacheco et al., 2011).

Freitas et al. (2010) collected blood samples from 75 carter horses in São José dos Pinhais and found 9.33\% positivity in the animals, with titers between 64 and 1,024 in the indirect immunofluorescence test for Rickettsia spp. 
In the present study, a positivity of $6.25 \%$ was found, showing that serological studies with intensively raised animals for Rickettsia positivity are lower in this way of breeding to a greater parasitic control in these animals in relation to the vectors of the disease, where tick infestations in these animals are smaller when compared to animals that live extensively.

The present study obtained results similar to those of other investigators who carried out serological studies for the presence of anti-Rickettsia spp., where it was found that it is common for the horse to cross-react with more than one type of Rickettsia spp. Also found in these studies were animals that reacted to the serological test for the presence of anti-Rickettsia spp. in places where the incriminated vectors of the disease were not found, contrasting with places where there were positive arthropods in real-time PCR for Rickettsia spp. and no seropositive animals (Batista et al., 2010; Medeiros et al., 2013; Toledo et al., 2009).

Areas that are used for ecotourism or human recreation and have occurrence of tick species known to be disease

\section{References}

Aragão HB. Ixodidas brasileiros e de alguns paizes limítrofes. Mem Inst Oswaldo Cruz. 1936;31(4):759-843. http://dx.doi. org/10.1590/S0074-02761936000400004.

Barros-Battesti DM, Arzua M, Bechara GH. Carrapatos de importância médico-veterinária da região neotropical: um guia ilustrado para identificação de espécies. São Paulo: Vox/ICTTD-3/Butantan; 2006.

Batista FG, Silval DM, Green KT, Tezza LBL, Vasconcelos SP, Carvalho SGS, Silveira I, Moraes-Filho J, Labruna MB, Fortes FS, Molento MB. Serological survey of Rickettsia sp. in horses and dogs in an non-endemic area in Brazil. Rev Bras Parasitol Vet. 2010;19(4):205-9.

Cardoso LD, Freitas RN, Mafra CL, Neves CVB, Figueira FCB, Labruna MB, Gennari SM, Walker DH, Galvão MAM. Caracterização de Rickettsia spp. circulante em foco silencioso de febre maculosa brasileira no Município de Caratinga, Minas Gerais, Brasil. Cad Saúde Pública, 2006;22(3):495-501.

CVE: Centro de Vigilância Epidemiológica Prof. "Alexandre Vranjac”. Febre maculosa brasileira. São Paulo: CVE; 2019. Informe Técnico II.

Freitas MC, Grycajuk M, Molento MB, Bonacin J, Labruna MB, Pacheco RC, Moraes-Filho J, Deconto I, Biondo AW. vectors require greater attention given the risk of infection and disease severity. Thus, further large studies should be conducted in the area targeting hosts and vectors to generate data for control measures of the transmission of Brazilian spotted fever.

\section{Conflict of Interest}

No conflicts.

\section{Ethics Statement}

The scientific research was authorized by the Ethics Committee of the Santo Amaro University (CEUA-UNISA), with approval protocol number 31/2016.

\section{Acknowledgements}

To São Paulo Research Foundation (FAPESP) for financial support (grant number 2016/22229-8 and 2016/00167-0).

Brazilian spotted fever in cart horses in a non-endemic area in Southern Brazil. Rev Bras Parasitol Vet. 2010;19(2):1301. http://dx.doi.org/10.1590/S1984-29612010000200013. PMid:20624353.

Guedes E, Leite RC, Prata MCA, Pacheco RC, Walker $\mathrm{DH}$, Labruna MB. Detection of Rickettsia rickettsii in the tick Amblyomma cajennense in a new Brazilian spotted fever-endemic area in the state of Minas Gerais. Mem Inst Oswaldo Cruz. 2005;100(8):841-5. http://dx.doi.org/10.1590/ S0074-02762005000800004. PMid:16444414.

Horta MC, Vianna MCB, Mafra CL, Schumaker TTS, Walker DH, Galvão MAM, Sangioni LA, Vidotto O, Gennari SM, Labruna MB. Prevalence of antibodies to spotted fever group rickettsiae in humans and domestic animals in a Brazilian spotted fever-endemic area in the state of São Paulo, Brazil: serologic evidence for infection by Rickettsia rickettsii and another spotted fever group Rickettsia. Am J Trop Med Hyg. 2004;71(1):93-7. http://dx.doi.org/10.4269/ ajtmh.2004.71.93. PMid:15238696.

Krawczak FS, Labruna MB, Hecht JA, Paddock CD, Karpathy SE. Genotypic characterization of Rickettsia bellii reveals distinct lineages in the United States and South America. BioMed Res Int. 2018;2018:1-8. http://dx.doi. org/10.1155/2018/8505483. PMid:29850579. 
Labruna MB, Kasai N, Ferreira F, Faccini JLH, Gennari SM. Seasonal dynamics of ticks (Acari: Ixodidae) on horses in the state of São Paulo, Brazil. Vet Parasitol. 2002;105(1):6577. http://dx.doi.org/10.1016/S0304-4017(01)00649-5. PMid:11879967.

Labruna MB, Ogrzewalska M, Soares JF, Martins TF, Soares HS, Moraes-Filho J, Nieri-Bastos FA, Almeida AP, Pinter A. Experimental Infection of Amblyomma aureolatum Ticks with rickettsia rickettsii. Emerg Infect Dis. 2011;17(5):829-34. http://dx.doi.org/10.3201/eid1705.101524. PMid:21529391.

Labruna MB, Pacheco RC, Richtzenhain LJ, Szabó MP. Isolation of Rickettsia rhipicephali and Rickettsia bellii from Haemaphysalis juxtakochi Ticks in the State of São Paulo, Brazil. Appl Environ Microbiol. 2007;73(3):869-73. http://dx.doi.org/10.1128/AEM.02249-06. PMid:17142361.

Labruna MB, Whitworth T, Horta MC, Bouyer DH, Mcbride JW, Pinter A, Popov V, Gennari SM, Walker DH. Rickettsia species infecting Amblyomma cooperi ticks from an area in the state of São Paulo, Brazil, where Brazilian spotted fever is endemic. J Clin Microbiol. 2004;42(1):90-8. http:// dx.doi.org/10.1128/JCM.42.1.90-98.2004. PMid:14715737.

Lemos-Monteiro J, Fonseca F, Prado A. Typho exantemático de São Paulo. Novas experiências sobre a transmissão experimental por carrapatos. Bras Med. 1932;16(48):993-5.

Martinelli M. Clima do estado de São Paulo. Revista FrancoBrasileira de Geografia. 2010;8(8):20-32.

Medeiros AP, Moura AB, Souza AP, Bellato V, Sartor AA, Vieira-Neto A, Moraes-Filho J, Labruna MB. Antibodies against rickettsiae from spotted fever groups in horses from two mesoregions in the state of Santa Catarina, Brazil. Arq Bras Med Vet Zootec. 2013;65(6):1713-9. http://dx.doi. org/10.1590/S0102-09352013000600019.

Murray GGR, Weinert LA, Rhule EL, Welch JJ. The Phylogeny of Rickettsia using different evolutionary signatures: how tree-like is bacterial evolution? Syst Biol. 2016;65(2):265-79.

Pacheco RC, Moraes-Filho J, Guedes E, Silveira I, Richtzenhain LJ, Leite RC, Labruna MB. Rickettsial infections of dogs, horses and ticks in Juiz de Fora, southeastern Brazil, and isolation of Rickettsia rickettsii from Rhipicephalus sanguineus ticks. Med Vet Entomol. 2011;25(2):148-55. http://dx.doi. org/10.1111/j.1365-2915.2010.00915.x. PMid:20950356.

Pinter A, Labruna MB. Isolation of Rickettsia rickettsii and Rickettsia bellii in cell culture from the tick Amblyomma aureolatum in Brazil. Ann N Y Acad Sci. 2006;1078(1):523-9. http://dx.doi.org/10.1196/annals.1374.103. PMid:17114770.

Piza JT. O carrapato como transmissor do Typho exanthemático de São Paulo? Boletim da Sociedade e Cirúrgica de São Paulo. 1932;15(2):350.

Ricketts HT. Some aspects of Rocky Montain Spotted, Fever as shown by recent investigations. Med Rec. 1909;(76):843-55.

Sangioni LA, Horta MC, Vianna MCB, Gennari SM, Soares RM, Galvão MAM, Schumaker TTS, Ferreira F, Vidotto O, Labruna MB. Rickettsial infection in animals and Brazilian Spotted Fever endemicity. Emerg Infect Dis. 2005;11(2):265-70. http://dx.doi.org/10.3201/eid1102.040656. PMid:15752445.

Silveira I, Pacheco RC, Szabó MPJ, Ramos HGC, Labruna MB. Rickettsia parkeri in Brazil. Emerg Infect Dis. 2007;13(7):1111-3. http://dx.doi.org/10.3201/eid1307.061397. PMid:18214195.

Toledo RS, Tamekuni K, Silva M Fo, Haydu VB, Barbieri AR, Hiltel AC, Pacheco RC, Labruna MB, Dumler JS, Vidotto O. Infection by spotted fever rickettsiae in people, dogs, horses and ticks in Londrina, Parana State, Brazil. Zoonoses Public Health. 2009;58(6):416-23. http://dx.doi. org/10.1111/j.1863-2378.2010.01382.x. PMid:21824336.

Ueno TE, Costa FB, Moraes-Filho J, Agostinho WC, Fernandes WR, Labruna MB. Experimental infection of horses with Rickettsia rickettsii. Parasit Vectors. 2016;9(1):499. http:// dx.doi.org/10.1186/s13071-016-1784-y. PMid:27624315.

Vieira AML, Souza CE, Labruna MB, Mayo RC, Souza SSL, Camargo-Neves VLF. Manual de vigilância acarológica estado de São Paulo. São Paulo: SUCEN; 2004. p. 62.

Weinert LA, Werren JH, Aebi A, Stone GN, Jiggins FM. Evolution and diversity of Rickettsia bacteria. BMC Biol. 2009;7(1):1-15. http://dx.doi.org/10.1186/1741-7007-7-6. PMid:19187530.

Financial Support: The scientific research was funded by FAPESP (São Paulo State Research Support Foundation), with case number 016/22629-6.

Authors Contributions: Claudia Iorio Budweg: collection of animal samples, performance of serological and molecular tests of the collected samples, analysis of the results found, elaboration of the scientific text. Amanda 
Oliveira de Sousa: realization of serological and molecular tests of the collected samples, analysis of the results found, elaboration of the scientific text. Tânia Regina Vieira de Carvalho: realization of serological tests of the collected samples, analysis of the results found, elaboration of the scientific text. Zahi Êni Santos Souza: conducting serological and molecular tests of the collected samples, analysis of the results found, elaboration of the scientific text. Maria Carolina de Azevedo Serpa: realization of serological tests of the collected samples, analysis of the results found, elaboration of the scientific text. Thiago Fernandes Martins: identification of arthropods, analysis of results and elaboration of the scientific text. Fernanda Nieri-Bastos: analysis of the results found, elaboration of the scientific text; Arlei Marcili: assistance in conducting molecular tests, analysis of results and elaboration of the scientific text. Marcelo Bahia Labruna: assistance in carrying out serological and molecular tests, analysis of results and elaboration of the scientific text. Jonas Moraes-Filho: conducting serological and molecular tests of the collected samples, analysis of the results found, elaboration of the scientific text, responsible for the scientific project and obtaining financial resources. 